\title{
Choosing Teaching as a Career: Motivations of Pre-service English Teachers in Turkey
}

\author{
Ece Zehir Topkaya \\ English Language Teaching Department, Faculty of Education, Çanakkale Onsekiz Mart University, Çanakkale, Turkey \\ Email: ecetopkaya@yahoo.com \\ Mehmet Sercan Uztosun \\ English Language Teaching Department, Faculty of Education, Çanakkale Onsekiz Mart University, Çanakkale, Turkey \\ Email: sercanuztosun@gmail.com
}

\begin{abstract}
This study examined the career motivations of pre-service English teachers at a state university in Turkey. For data collection, an adapted version of the Factors Influencing Teaching Choice Scale was used and 207 pre-service teachers were surveyed. The findings revealed that social utility and intrinsic values of teaching were important career motivations for the participants which were followed by ability related beliefs. Both male and female participants were more intrinsically and socially motivated, while male participants had higher ratings for job security and employment possibilities. There was not a statistical difference between first and fourth graders' career motivations.
\end{abstract}

Index Terms - career motivations, pre-service teachers, English language teaching

\section{INTRODUCTION}

Personal and professional characteristics of good teachers have been vastly stated in research on teacher education (see for example Larsen-Freeman and Long, 1991; Bailey, 1985; Miller 1987; Prodromou, 1991; Scrivener, 1994). However, what knowledge, beliefs, motivations, and background experience they bring to their roles as teachers are also worth studying since such studies help teacher educators better understand who their students are and they also offer new insights into teacher education process and curriculum development (Brookhart and Freeman, 1992).

In literature on pre-service education, there is also a growing body of research on the attractors affecting the choices people make to pursue a career in teaching. All around the world this issue has gained importance for it is becoming increasingly difficult to motivate young people to the teaching profession as well as keeping the trained force within the profession (Watt and Richardson, 2007; Taylor, 2006; Moran et al., 2001). Moreover, as it is stated by Watt et al. (2007), students' personal beliefs, preconceptions and reasons for choosing teaching as a career shape their "aspirations for professional engagement and the trajectory of their career development" (p.155).

In the Turkish context studies on teacher career motivations have also gained momentum for the last decade. Several studies have been conducted to understand the profiles of Turkish pre-service teachers from specific teaching programs such as pre-school, elementary school, mathematics and biology teaching departments (see Kabaday1, 2008; Saban, 2003; Kılınç and Mahiroğlu, 2009; Aksu et al. 2010; Özsoy et al., 2010). This endeavor to provide insights into different subject areas is also the concern of the researchers of this current study. Thus, this study aims to identify those career motivations prevalent among pre-service English language teachers.

\section{A. A Brief Look at Types and Theories of Career Motivations}

The motives for selecting teaching as a career are various. Research studies mainly indicate three basic types or categories of motives for selecting teaching as a career: a. extrinsic motives such as salary, lengthy holidays; b. intrinsic motives such as interest, personal experience, and intellectual fulfillment, and c. altruistic motives as wanting to contribute to the growth of another individual (Moran et al., 2001; Brookhart and Freeman, 1992).

Apart from these traditional conceptualizations, starting from 1950s, several theories of career choice have been developed. One of the earliest ones is Super's self-concept theory (1953) which drew upon the role of individuals' perception of self in choosing a career. According to the theory, the question "Who I am?" is a key factor that plays a determinative role in individuals' choosing a profession. Holland (1959), on the other hand, named this factor as "selfknowledge" and claimed that a good occupational choice depends not only individuals' accurate self-knowledge but also accurate occupational knowledge. In other words, besides developing self-awareness, individuals should also be knowledgeable about the characteristics of the occupation so as to generate an idea whether it is suitable for them. Another theory proposed by Gottfredson (1981) asserts that career choice is determined by two variables, that is, sextype rating and prestige level, which means that people choose particular occupations by examining features of that job regarding its suitability to their gender and its level of prestige. 
In addition to these, self-efficacy, a construct first proposed by Bandura (1986), is also considered as an important source of motivation in decision-making process since individuals' perception of their ability to perform an occupation determines whether they will choose that occupation or not.

Yet, some other research studies have looked into theories of motivation in an attempt to identify basis in the career selection process. Drawing upon expectancy-value theory, one of the cognitive theories of achievement motivation, some of these studies suggest that expectations of success and the subjective value of the task are major determinants of motivation for academic choices as well as career choices (Wigfield and Eccles, 2000; Richardson and Watt, 2005; Eggen and Kauchak, 2007). Expectancy for success is influenced by two factors: perceptions of task difficulty and beliefs about one's abilities. That is, it is likely that when people perceive a task as easy, they will put more effort in completing it and similarly people with positive self-concept of ability will have higher expectations of success and therefore be more willing and motivated to invest time and energy into a task. Task value, on the other hand, is influenced by four factors namely intrinsic values, utility value, attainment value and cost. Intrinsic values refer to the pleasure one takes from doing a task, while utility value refers to the usefulness of a task for the individual's future. Attainment value is related to the importance of doing well on the task. Lastly, cost is what the individual has to sacrifice to carry out the task, as well as the effort required to complete it (Eggen and Kauchak, 2007; Richardson and Watt, 2005; Watt and Richardson, 2007).

Taken together, this brief discussion of theories illustrates the fact that individual's career motivations can be explained in a variety of ways depending on one's approach to the issue. Similarly, the literature review of some studies carried out around the world and documented below also supports these different perspectives taken while interpreting the motives behind teachers' career choice.

\section{B. Choosing Teaching as Career}

Studies related to the motives lying behind choosing teaching as a career abound in literature. Using both qualitative and quantitative techniques for investigation, majority of them base their interpretations on the traditional classification of intrinsic, extrinsic and altruistic attractors. For example, Hayes (1990 cited in Moran et al., 2001) found that in a cohort of American students entering teaching altruistic reasons such as making a positive difference in the lives of children were more significant. Similarly, Stiegelbauer (1992 cited in Fullan, 1993) reported that in her study with Canadian prospective teachers, the need to make a difference to students and society as well as the desire to be role models for students emerged as the main themes for entering the profession. Hammond (2002), in a small scale study including trainee teachers of information and communication technology, found that trainees frequently drew upon their own past experience of teaching as well as their own interest to explain their career choice. On the other hand, in their comparative study of Norwegian and British pre-service teachers, Kyriacou et al. (1999) reported that the participants rated "enjoying teaching" and "enjoying working with children" higher than the other factors, placing more emphasis on intrinsic reasons. Yet, in another study, Sinclair (2008) found that prospective teachers are multi-motivated. In her study, the primary pre-service teachers stated to have the necessary qualities and attributes to be teachers and to work with children as their basic sources of motivation to become teachers besides the factor that they found teaching intellectually stimulating. As can be seen, it is difficult to generalize the reasons why students choose teaching as a career. The variety in their responses may be due to the cultural, social, and economic contexts they live in (Kyriacou et al., 1999) as well as the subject areas they will teach.

In another study, Watt and Richardson (2007), on the other hand, used a comprehensive scale named Factors Influencing Teaching Choice (FIT-Choice), which they developed (Richardson and Watt, 2006) heavily relying on the expectancy-value theory. They conducted the study with pre-service teachers enrolled in three Australian universities and found that perceived teaching abilities, the intrinsic value of teaching and the desire to make a social contribution were the highest rated motivations.

As stated in the introduction, in Turkey not many studies have been conducted. Those undertaken, however, present different results. For example, in one of the earlier studies Saban (2003) found that prospective elementary school teachers considered altruistic reasons to be more important and the extrinsic ones such as getting a secure job and a steady monthly income as more influential than intrinsic reasons in their career choice. In another study, Gürbüz and Sülün (2004) reported that prospective biology teachers were primarily motivated by their love for biology, while they rated the extrinsic motive of "job security" as the second reason for choosing teaching career. Similarly, Kılınç and Mahiroğlu's study on biology pre-service teachers yielded the same results (2009). According to the findings of a qualitative study carried out by Boz and Boz (2008), prospective chemistry and mathematics teachers were influenced by both intrinsic and extrinsic values emphasizing that especially prior positive experience with the subject itself and teachers play a determining role on the choice of teaching career. In a large scale study Aksu et al. (2010) investigated the profiles of prospective teachers from different teaching programs and found that more than half of the students voluntarily chose to become teachers. On the other hand, the same group of participants reported more extrinsic reasons such as job security, flexible hours and holidays as well as the possibility of "engaging in a secondary employment" as motives that led them to select teaching for a profession. Özsoy et al. (2010) also conducted a large scale study comprising pre-service teachers from four universities and found that the majority of the participants chose teaching not as a "fallback" career, i.e. a last-resort one, but because it was their ideal to teach. Based on this sample of studies done 
in Turkey, it could be concluded that Turkish prospective teachers of different subject areas are primarily led by intrinsic and altruistic reasons but also heavily affected by extrinsic factors such as job security and regular income.

However, there has been a dearth of research on the career motivations of prospective English language teachers. Therefore, this study, addressing this gap in research, is an attempt to contribute to our understanding of why this particular group chooses to become teachers with its focus on pre-service English teachers. It is hoped that the results and implications will contribute to the growth of existing literature on the issue and help teacher educators, curriculum developers and policy makers better understand and improve the quality of pre-service teacher education.

\section{Becoming an English Teacher in Turkey}

There are two types of secondary schools, general and vocational-technical, that educate those students who wish to pursue a career in language teaching in Turkey. General secondary schools encompass four years of schooling including two phases: common and division-based education. In the first phase, which lasts a year, all students take compulsory common courses such as Turkish Literature, Mathematics, Physics, History, English etc. The second phase comprises division courses that students have to take depending on their decisions about the field of study they would like to pursue. There are four main types of divisions: Positive sciences, social sciences, Turkish-Mathematics and Foreign Language. This selection might be considered as a turning point in a student's career because they can only prefer departments pertaining to their divisions of graduation while entering university. In this respect, foreign language departments of universities can be preferred by those students who graduate from language divisions of secondary schools.

On the other hand, vocational schools which are called Anatolian Teacher Training High Schools also train students for faculties of education through providing pedagogical courses during their secondary education. For that reason, these students are given extra credits in University Entrance Exam on condition that they choose a career in teaching. Within the selection process, firstly, students take Student Selection Examination (ÖSS) which is centrally administered by Student Selection and Placement Centre (ÖSYM) and secondarily, The Foreign Language Examination (YDS). While the former refers to students' proficiency in the Turkish language, using social science concepts and their mathematical abilities, the latter is concerned with students' English proficiency (ÖSYM, 2006). The English test contains one hundred multiple-choice items covering vocabulary, grammar and reading skills. After the announcement of scores, the prospective university students fill in a preference form and according to their rankings and percentiles enrol in universities.

The entrance age range among Turkish university students does not show variety since as a developing country, career switching or doing another major is not a common phenomenon in Turkey. For this reason, after completing secondary education at the age of 17 or 18 students become eligible candidates for English language teaching departments of faculties of education and they usually complete their undergraduate studies within four or five years time.

However, being an English language teacher in Turkey is not limited to students who graduate from English language teaching departments. Graduates of six other departments functioning under faculties of Science and Letters are also entitled as English language teachers provided that they complete a pedagogical formation course which aims to compensate graduates' lack of knowledge about teaching. To clearly depict the case in Turkey the following figure is provided (see Figure 1).

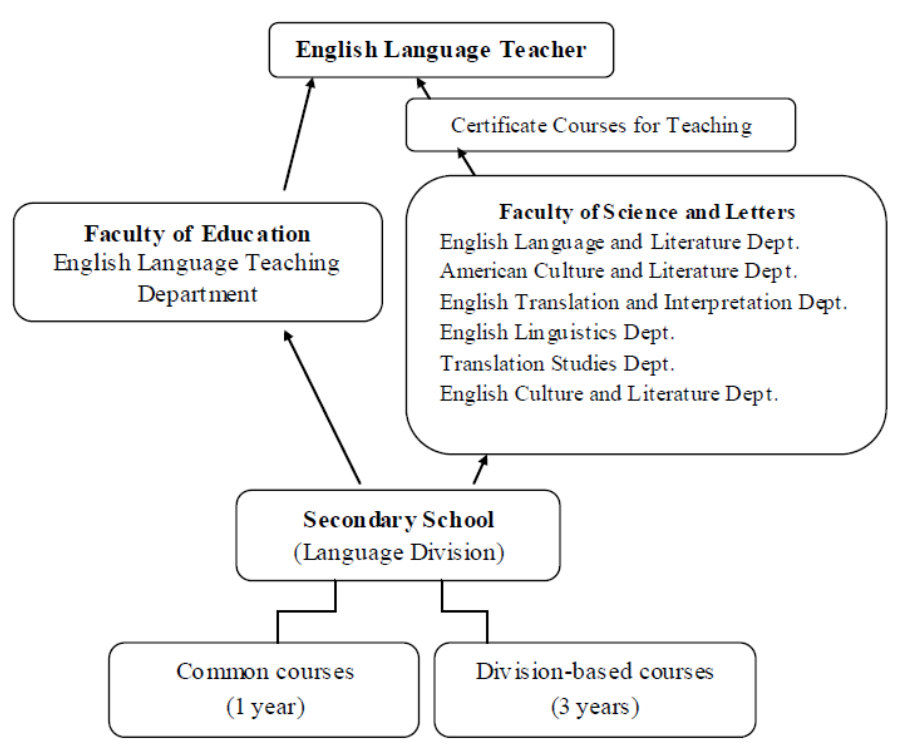

Figure 1. Paths to becoming an English teacher in Turkey 


\section{THE STUDY}

\section{A. Research Problem and Questions}

The main purpose of this study is to gain insight into the factors influencing people's decisions who choose teaching English as a career. In relation to this purpose, thus, this study seeks answers to the following questions:

1. What are the career motivations of pre-service English language teachers?

2. Is there a relationship between pre-service English language teachers' career motivations and their gender?

3. Is there a relationship between pre-service English language teachers' career motivations and their grade levels?

\section{B. Methodology}

This study follows a quantitative methodology within a theory-based approach tapping Watt's and Richardson's (2007) conceptualization to interpret career motivations of pre-service English language teachers in Turkey. The survey method was taken up as the main methodology since gathering data from a relatively large number of cases was required and the survey methodology enables researchers to gather information that people are able to report about themselves, such as their beliefs and motivations (Best and Khan, 2006; Mackey and Gass, 2005).

\section{Setting and Participants}

The study took place at Çanakkale Onsekiz Mart University in the spring term of 2008-2009 academic year. The participants were students at ELT Department at the Faculty of Education. 207 students were invited to join the study all of whom voluntarily agreed to participate and the final sample consisted of 207 first and fourth grade pre-service teachers. The following table shows the personal characteristics of the sample (see Table 1).

TABLE 1.

PARTICIPANTS' DEMOGRAPHIC CHARACTERISTICS

\begin{tabular}{|c|c|c|}
\hline Characteristics & $\mathrm{f}$ & $\%$ \\
\hline \multicolumn{3}{|l|}{ Class } \\
\hline First & 104 & 50.2 \\
\hline Fourth & 103 & 49.8 \\
\hline \multicolumn{3}{|l|}{ Gender } \\
\hline Male & 38 & 18.4 \\
\hline Female & 169 & 81.6 \\
\hline
\end{tabular}

As seen in the table, $104(50 \%)$ of the participants were first and 103 (49.8) of them were fourth grade learners. Of these while a majority was female prospective teachers $(81.6 \%)$ only $38(18.4 \%)$ of them were male pre-service teachers. The prevailing construction of teaching in Turkey as well as around the world is that of a feminized occupation. Thus, the finding here also confirms that entering teacher candidates are typically female, which is also evidenced in the studies of Aksu et al. (2010), Saban, (2003), and Watt and Richardson (2007).

\section{Instruments}

To collect the data a two- part questionnaire was prepared. The first part asked for demographic information such as age, gender, status of study. In the second part, an adapted version of the Factors Influencing Teaching Choice (FITChoice) Scale (Watt and Richardson, 2007) with 23 items that were grouped under 6 subscales was used. In this part a prefacing statement to all items was written: "I chose to become a language teacher because..." and the respondents were asked to rate the importance of each factor on their choice of teaching as a career on a seven-point Likert scale with the anchors ranging from not al all to extremely. The questionnaire was completed in a class hour. No difficulties were reported by the respondents who filled out the survey instruments fully without causing any data loss.

The adaptation of the FIT-choice scale

The FIT-Choice scale was originally grounded in the expectancy-value theory of motivation. However, it not only reflects the principal aspects of this theory but also draws upon social cognitive theory and the literature on teacher education and career choice (Richardson and Watt, 2006).

The original scale includes 3 main parts designed to elicit data about the motivations for teaching, perceptions about the profession and career choice satisfaction. The scale related to career motivation includes the "intrinsic values" (individuals' interest in and desire to teach), "personal utility values" (reasons related to job security, time for family, job transferability), "social utility values" (individuals' desire to shape future of children/adolescents, enhance social equity, make social contribution, work with children/adolescents), "self perceptions of individuals' own teaching abilities"(individuals' perceptions of their teaching abilities), "fallback career choice" (individuals' selection of teaching as a career because they have not been accepted into their first choices), "socialization influences" (prior teaching and learning experiences, peers' or parents' influence on their decisions) subscales (Richardson and Watt, 2006; Watt and Richardson, 2007).

While adapting the instrument, both for the purpose of this particular study and also due to certain contextual reasons some of the items in this scale were rewritten while some of them were left out. For instance, since the FIT-Choice scale was not particularly developed to gather the career motivations of English language teachers, the terms "language" and "language teacher" were included to the items wherever appropriate. It was thought that in this way the items would 
make more sense to the respondents who were language teacher candidates. Therefore, for example, item 21 in the original scale which stated "I have the qualities of a good teacher" was turned to "I have the qualities of a good language teacher". As for the exclusion of some of the items, for example, the group of items put under the factor of job transferability that read "teaching will be a useful job for me when travelling" or "A teaching job will allow me to choose where I wish to live" were excluded since they are not applicable for Turkish foreign language teachers who are non-native speakers of English and therefore barely travel around the world to teach English. After these adaptations, the scale was given its final form including 23 items with two negative ones, which were all in English. One item to check the consistency of the respondents was added which asked them to give the same response that they previously gave to a different item. The Pearson's Correlation analysis conducted between these items revealed a high positive correlation $(r=.979, \mathrm{p}<.01)$.

The adapted version of the scale was pilot tested with a group of 165 pre-service English teachers not participating in the main study and pre-service German teachers who checked the clarity of the items. According to their feedback some minor changes were made in the wording of the statements. After the data was collected, its reliability analysis was also carried out. The following table presents the findings (see Table 2).

TABLE 2.

\begin{tabular}{|c|c|c|}
\hline & Factors & Alpha values \\
\hline & Self-perception & .78 \\
\hline & Intrinsic Values & .71 \\
\hline & Personal Utility & .85 \\
\hline & Social Utility & .88 \\
\hline & Socialization Influences & .76 \\
\hline & Fallback Career & .83 \\
\hline
\end{tabular}

As the table shows, for all the factors the analysis yielded high reliability values.

\section{FINDINGS AND DISCUSSION}

Below the findings are presented in relation to the research questions.

\section{A. Research Question 1. Career Motivations of Pre-service English Language Teachers}

The preliminary data analysis revealed that participants had moderately high level of career motivations $($ Mean= 4.82; $\mathrm{SD}=.89$ ). When the mean ratings for each item are studied, it is seen that participants placed a high value on their liking teaching more than the other reasons (Mean=5.69; $\mathrm{SD}=1.52$ ), which indicates that they were more intrinsically motivated in their career choice. However, the following 4 top rated reasons are those related to altruistic motivations, all placed under social utility value in the scale. These are; "teaching will allow me to shape child and adolescent values", "Teaching will allow me to influence the next generation", "Teaching will provide me to provide service to society" and "teachers make a worthwhile social contribution". These findings were in line with the findings of Stiegelbauer (1992 cited in Fullan, 1993), Gürbüz and Sülün (2004) and Saban (2003) who also reported that intrinsic motivations as well as those related to making contributions to the lives of others and society were the major attractors for entrant teachers. Similarly, Watt and Richardson (2007) in their study with a cohort of pre-service teachers from 3 Australian universities using the FIT-Choice scale also pointed to the same motivators as being the most important ones.

The least influential reason for participants' career choice, on the other hand, was choosing teaching as a fallback career. The items "I was not accepted as into my other career choices" and "I chose teaching as a last resort career" were indicated as the least influential factors which were followed by social influences of other people around them. However, it should be noted that while participants rated those motivators related to social influences by other people around them such as their parents low (Mean=3.10; $\mathrm{SD}=2.04$ ), they reported "having good teachers as role models" as more influential in their choice for teaching career (Mean=5.29; $\mathrm{SD}=1.72$ ), a case which has been emphasized in other studies as well (see for example Stiegelbauer, 1992 cited in Bastick, 2000; Boz and Boz, 2008; Aksu et al. 2010).

The data was submitted to further descriptive analysis to understand participants' overall career motivations in relation to the sub factors of the scale. Table 3 below presents the mean ratings for each motivation.

TABLE 3

\begin{tabular}{lll} 
MEAN VALUES FOR FACTORS INFLUENCING TEACHING CHOICE \\
\hline Career Motivations & Mean & SD \\
\hline Social Utility Values & 5.2895 & 1.16550 \\
Intrinsic Values & 5.2657 & 1.52310 \\
Self -perceptions & 4.9348 & 1.28730 \\
Personal Utility Values & 4.2842 & 1.36073 \\
Socialization Influences & 4.2126 & 1.23967 \\
Fallback Career & 1.8267 & 1.57552 \\
\hline
\end{tabular}

While the highest rated motivations for choosing teaching as a career included social utility, the intrinsic value of teaching and participants' perceived teaching abilities, choosing teaching as a fallback career was the lowest rated 
motivation. This finding is especially interesting since there are studies evidencing that students choose teaching as a last resort career (see Yong, 1995; Klassen et al., 2011). However, the findings of this particular study and several others (see Aksu et al., 2010; Özsoy et al., 2010; Watt and Richardson, 2007) did not provide support for this opinion.

\section{B. Research Question 2. Career Motivations of Pre-service English Teachers in Relation to Gender}

The second research question sought answers for the question what career motivations participants had in relation to their gender and whether these were significantly related. The initial descriptive analysis showed that female participants reported intrinsic career value "I like teaching" as their top motivation for choosing teaching as a career, followed by social utility values and socialization influences (prior positive learning and teaching experience). These findings were consistent with those reported by Saban (2003), who also found that female students had more altruistic and intrinsic motivations than males. The analysis also revealed that the lowest rated motivations for female participants were fallback career, social influences of other people around them. In this group, items "As a teacher I will have lengthy holidays" and "I will have a short work day" which refer to bludging under the personal utility values scale received lower ratings. The male participants, similarly, placed more value on social utility values followed by intrinsic career values. However, among the top rated 9 items those related to job security (Item 6) and employment opportunities (Item 14) also received higher ratings by male participants (Mean=5.10, SD=1.73; Mean=5.03, SD=1.74 respectively). This finding is also congruent with those in other studies (Bookheart and Freeman, 1992; Saban, 2003; Richardson and Watt, 2006; Kılınç and Mahiroğlu, 2009).

The overall results of the initial descriptive statistics with the mean ratings for gender differences are presented in the table below.

TABLE 4

GENDER DIFFERENCES FOR CAREER MOTIVATIONS.

\begin{tabular}{llll}
\hline Factors & Gender & Mean & SD \\
\hline Intrinsic Values & Female & 5.3313 & 1.53681 \\
\multirow{2}{*}{ Social Utility Values } & Male & 4.9359 & 1.28681 \\
& Female & 5.3126 & 1.17895 \\
Self-perceptions & Male & 5.1410 & 1.16115 \\
& Female & 4.9663 & 1.29234 \\
Personal Utility Values & Male & 4.7692 & 1.28681 \\
& Female & 4.2536 & 1.37318 \\
Socialization Influences & Male & 4.5556 & 1.26082 \\
& Female & 4.2193 & 1.25192 \\
Fallback Career & Male & 4.2244 & 1.24710 \\
& Female & 1.8037 & 1.54304 \\
& Male & 1.9231 & 1.72268 \\
\hline
\end{tabular}

However, as displayed in Table 4, the independent samples t-test analysis revealed no statistically significant differences between the gender of the participants and their career motivations ( $p>.05$ ). Similarly, Kılınç and Mahiroğlu (2009) pointed out that the biology student teachers in their study did not report gender based career motivations. This is also supported by Richardson and Watt's study (2005) investigating factors influencing career choice at an Australian University. Out of five different factors as social status, career fit, prior considerations, financial reward and time for family, the only significant difference was about prior considerations. In that vein, Johnston et al.'s study (1999) in British context revealed that male and female primary teacher trainees are in agreement about factors influenced their decisions to enter teaching profession, namely, perceived job satisfaction, contribution to society, imparting knowledge, job security, mentally stimulating work, good holidays, respectable job, family approval, status and promotion prospects. However, they elucidated significant gender difference about two factors as working with children and salary, which showed that males placed less emphasis on the importance of working with children but more emphasis on salary.

The results of these studies illustrate that, although males and females are reported to be in the same line about the effects of the majority of aforementioned factors, further empirical studies are required to understand the place of gender as the factor influencing individuals' reasons for entering teaching as a profession.

As for the grade differences, the mean ratings were also calculated and put in the table below. 
TABLE 5

GRADE DIFFERENCES FOR CAREER MOTIVATIONS.

\begin{tabular}{llll}
\hline Factors & Grades & Mean & SD \\
\hline Intrinsic Values & First & 5.2374 & 1.34802 \\
Social UtilityValues & Fourth & 5.0245 & 1.23757 \\
& First & 5.2066 & 1.26200 \\
Self -perceptions & Fourth & 5.3490 & 1.09098 \\
& First & 4.8283 & 1.34802 \\
Personal Utility Values & Fourth & 5.0245 & 1.23757 \\
& First & 4.2111 & 1.42625 \\
Socialization Influences & Fourth & 4.4062 & 1.28725 \\
& First & 4.1052 & 1.20159 \\
Fallback Career & Fourth & 4.3366 & 1.29200 \\
& First & 1.7374 & 1.52252 \\
& Fourth & 1.9216 & 1.63311 \\
\hline
\end{tabular}

As Table 5 illustrates, first graders rated intrinsic values, social utility values and self-perceptions of language and teaching abilities higher than the other ones. In line with the former group, fourth graders also rated intrinsic values, social utility values higher than the others as the other two sources of motivations, namely personal utility values and socialization influences, were rated in between. However, while the $1^{\text {st }}$ graders indicated intrinsic values as the main sources of their career choice, the $4^{\text {th }}$ graders showed social utility values as more influential. This difference in perception might be due what prospective teachers experience during their teacher education. While they enter the faculty being only concerned about what they enjoy doing, through years of study and teaching experience during School Experience and Practicum courses they start observing how teaching is socially important. Certainly, to be able to determine whether such changes in perceptions do occur or not, longitudinal studies should be conducted.

Not surprisingly, the fourth graders also indicated those factors related to their self-perceptions of abilities in teaching and language as more influential in their career choice. This difference in perceptions may also be related to the effect of training at the faculty as explained above. Literature also points out that especially teaching experience has an effect on the self-efficacy perceptions of pre-service teachers (Eslami and Fatahi, 2008).

Lastly, for both grade levels, fallback career was the lowest rated career motivation. Similar to gender, the independent samples t-test analysis yielded no statistically significant differences between the grade levels and sub dimensions of career motivations ( $\mathrm{p}>.05)$.

\section{CONCLUSIONS AND IMPLICATIONS}

This study aimed to obtain insights into career motivations of pre-service English language teachers in a particular university in Turkey. Overall, the sample in this study featured high levels of career motivations. Therefore, it could be concluded that in terms of occupational motivations these student teachers were enthusiastic to enter teacher education.

The mean values for the sub dimensions of social utility, intrinsic values, self-perceptions, personal utility values and socialization influences being moderately high, on the other hand, indicate that reasons for entering teaching for this sample are multi-faceted as stated in another study by Sinclair (2008). Most noticeably, the motives for selecting teaching career in this cohort were headed by social utility values and intrinsic career values. As it was documented by several researchers such as Yong (1995), Bastick (2000) and Klassen et al. (2011) especially in developing countries the reasons given for the motives to enter teaching emphasize extrinsic attractors in comparison to English speaking metropolitan countries where intrinsic and altruistic motivations are reported as the main sources of career motivations. As Yong (1995) reported, "extrinsic" entry career motives of pre-service teachers may undermine their long-term commitment to teaching. Thus, the overall findings of this current study could be interpreted as positive and promising not only for pre-service English language teacher education which aims to train quality teachers but also for but also schools where these prospective teachers will find job opportunities after graduation. Yet, whether these motives are shared by other prospective teachers or not needs to be researched involving larger samples from different universities to be able to elaborate more on the results obtained here.

Of particular note in this study was the finding that the choice of teaching career was a voluntary one rather than a fallback career, which contradicts the general public opinion that teaching is a poor choice. Although the data in this study came from only one English language teaching department in Turkey, several other studies conducted with different subject area pre-service teachers with similar findings (see for example Aksu et al., 2010; Özsoy et al., 2010) seem to support the suggestion that this result may be considered as a sign of raising standards in teacher education with regard to career choice decisions in Turkey.

Together with the fallback career, parents' and other people's such as friends' influence was the other attractor which was found to be rated low by the participants. As opposed to this finding, however, the prospective teachers in this study reported the influence of prior teachers as role models as one of the main reasons for their career choice. Literature is replete with studies that have shown time and again that teacher is the "most influential school-related force in student achievement" (Stronge, 2007, p. x). Similarly, having positive teacher role models also appears to be a significant factor for career choice decisions (Stiegelbauer, 1992 cited in Bastick, 2000). It is already known that skilled and qualified teaching workforce can influence young people's lives by portraying images of good teaching and 
demonstrating good professional and personal traits. This fact, therefore, emphasizes the need to supporting practicing teachers by providing them with opportunities for professional as well as personal development through in-service training and other academic activities. This, in return, calls for more strategic and long term planning and investment by Ministries of Education.

As for the relationship between gender of the participants and career motivations no statistically significant difference was found in this study. Both groups in differing degrees put emphasis on the influence of those motives that come under the sub dimensions of intrinsic, social utility values and self-perceptions, although female participants were observed to have higher ratings. On the other hand, male participants perceived those motives related to the other three sub dimensions, personal utility values, socialization influences and fallback career as slightly more influential on their choice of career than female participants. Although not found statistically significant, male participants' emphasis on financial rewards of the occupation suggests that "economic survival maybe a far more relevant issue than selfrealization" (Fitzgerald and Betz, 1994, p.104) or any other higher order, altruistic motives. Especially those reasons such as job security, steady income, and lengthy holidays seem to be regarded more by males, which is not surprising for the Turkish context where economic uncertainties cause many people to lose their jobs especially in private sector where teachers are left with no legal protection against the hiring and firing policies of these institutions (Aksu et al., 2010).

Similar to gender, this current study did not find a significant difference between grade levels and career choice motivations of the participants. One of the reasons for looking into the $1^{\text {st }}$ and $4^{\text {th }}$ grade prospective teachers' motivations in this study was to see whether training has an effect on their perceptions. As the findings suggest, except intrinsic values, the $4^{\text {th }}$ graders rated all other sources of career motivations higher than the first graders did, which might indicate a shift in view due to the training prospective teachers receive. However, to be able to make definite and reliable conclusions they should be observed and studied all through their years of education, which is an implication for further research.

The impact that career choice has on people is a long-term one and an unwilling choice may lead to low academic achievement during pre-service education. Since the quality of pre-service teacher is closely related to the motivations, beliefs, attitudes and perceptions of prospective teachers, understanding these established psychological constructs gains importance. Only with such an insight could it be possible to develop training programs and attempt to change their entering beliefs. While doing so we should not forget that these ideas and beliefs once set determine the practices of teachers in real classrooms.

An unwilling choice of career not only jeopardizes the quality of teacher education but also is reflected in dissatisfaction and early burnout in future career (see for example Kan, 2008; Dolunay, 2002). Therefore, young people who choose to be teachers primarily because they are inspired by those factors such as their love for children and teaching or by the motive to help others grow may be considered as indicators of better induction into future roles. Yet, in the Turkish context it is not the sustainable employment but a lack of commitment to teaching and efforts for professional development which form the basis of teacher-related problems. As this study revealed high levels of entry career motivations supporting the similar findings of different studies, then probably more should be done to investigate how and why these highly motivated individuals lose their enthusiasm to teach and stay up-date. This issue calls for following graduates once they start teaching and investigating those reasons lying behind their burn-out.

Lastly, it should be noted that there are limitations that pertain to the data set in this study. To begin with, this study examined the career motivations of pre-service English teachers enrolled in a department of a particular state university in Turkey. As such being the case, the findings cannot be said to depict the full picture of all pre-service teachers' career choice motivations. Therefore, similar studies comprising different samples from different English Language Teaching departments should be conducted to better understand the career motivations of prospective English language teachers.

\section{REFERENCES}

[1] Aksu, M., Demir, C.E., Daloğlu, A., Yıldırım, S., Kiraz, E. (2010). Who are the future teachers in Turkey? Characteristics of entering student teachers, Journal of Educational Development 30, 91-101.

[2] Bailey, K. M. (1985). Classroom-centered research on language teaching and learning. In Celce-Murcia, M. (ed.), Beyond Basics: Issues and Research in TESOL. Rowley, Mass.: Newbury House.

[3] Bandura, A. (1986). The explanatory and predictive scope of self-efficacy theory. Journal of Clinical and Social Psychology 4, 359-373.

[4] Bastick, T. (2000). Why teacher trainees choose the teaching profession: comparing trainees in metropolitan and developing countries, International Review of Education 6.3-4, 343-349.

[5] Best, J.W. \& Khan, J.V. (2006). Research in Education (10 ${ }^{\text {th }}$ edn.). Boston: Pearson Education Inc.

[6] Brookhart, S. M. \& Freeman, D.J. (1992). Characteristics of Entering Teacher Candidates, Review of Educational Research, 62.1, 37-60.

[7] Boz, Y. \& Boz, N. (2008). Kimya ve matematik öğretmen adaylarının öğretmen olma nedenleri, Kastamonu Eğitim Dergisi, 16.1, 137-144. Retrieved May 1, 2010, from http://www.kefdergi.com/pdf/cilt-16-no1-2008Mart/137.pdf

[8] Dolunay, A. D. (2002). Genel liseler ve teknik-ticaret-meslek liselerinde görevli öğretmenlerde tükenmişlik durumu, Ankara Üniversitesi Tip Fakültesi Mecmuasi 55.1, 51-62.

[9] Eggen, P. \& Kauchak, D. (2007). Educational Psychology (7th edn.). New Jersey: Pearson Education International. 
[10] Eslami, Z. R. \& Fatahi, A. (2008). Teachers' sense of self-efficacy, English proficiency, and instructional strategies: A study of non-native EFL teachers in Iran, TESL-EJ 11.4, Retrieved April, 12, 2010, http://tesl-ej.org/ej44/a1.pdf

[11] Fitzgerald, L. F. \& Betz, N. E. (1994). Career development in cultural context: The role of gender, race, class, and sexual orientation. In M. L. Savickas \& K. W. Lent (eds.), Convergence in career development theories: Implications for science and practice (pp. 103-117). Palo Alto, CA: Consulting Psychologists Press.

[12] Fullan, M. G. (1993). Why teachers must become change agents, Educational Leadership 50.6,12-17.

[13] Gottfredson, L. S. (1981). Circumscription and compromise: A developmental theory of occupational aspirations. Journal of Counseling Psychology (Monograph), 28.6,545-579.

[14] Gürbüz, H. \& Sülün, A. (2004). Türkiye'de biyoloji öğretmenleri ve biyoloji öğretmen adaylarının nitelikleri, Milli Eğitim Dergisi 161, 193-199.

[15] Hammond, M. (2002). Why Teach? A case study investigating the decision to train to teach ICT, Journal of Education for Teaching: International Research and Pedagogy 28.2, 135-148.

[16] Holland, J. L. (1959). A theory of vocational choice. Journal of Counseling Psychology, 6.1, 35-45.

[17] Kabaday, A. (2008). Investigating demographic characteristics and teaching perceptions of Turkish pre-school teachers. Early Child and Development Care, 1-13.

[18] Kan, Ü. D. (2008). Bir grup okulöncesi öğretmeninde tükenmişlik durumunun incelenmesi, Kastamonu Eğitim Dergisi 16.1, 431-438.

[19] Kılınç, A. \& Mahiroğlu, A. (2009). The attractors of teaching Biology: A perspective from a Turkish context, Australian Journal of Teacher Education 34.5, 15-39.

[20] Klassen, R. M., Al-Dharfi, S., Hannok, W. \& Betts, S.M. (2011). Investigating pre-service teacher motivation across cultures using the Teachers' ten statements test, Teaching and Teacher Education, 27.3, 579-588.

[21] Kyriacou, C., Hultren, A. \& Stephens, P. (1999). Student teachers' motivation to become a secondary school teachers in England and Norway, Teacher Development 3, 373-381.

[22] Larsen-Freeman, D. \& Long, M. H. (1991). An introduction to second language acquisition research. London: Longman.

[23] Mackey, A. \& Gass, S. M. (2005). Second language research. New Jersey: Lawrence Erlbaum Associates.

[24] Miller, P. (1987). Ten characteristics of a good teacher, English Teaching Form 25.1, 40-41.

[25] Moran, A., Kilpatrick, R., Abbott, L., Dallat, J. \& McClune, B. (2001). Training to teach: motivating factors and implications for recruitment, Evaluation and Research in Education 15.1, 17-32.

[26] Özsoy, G., Özsoy, S., Özkara, Y., Memiş, A. D. (2010). Factors affecting pre-service teachers' choice of teaching as a profession, Elementary Education Online 9.2, 910-92. Retrieved February 12, 2010, from http://ilkogretimonline.org.tr/vol9say3/v9s3m7.doc

[27] ÖSYM. (2006). Selection and placement of students in higher education institutions in Turkey. Ankara: OSYM. Retrieved 18 July 2010 from http://www.osym.gov.tr/BelgeGoster.aspx?F6E10F8892433CFF7A2395174CFB32E15F640FC6104C033D.

[28] Prodromou, L. (1991). The good language teacher, English Teaching Forum 29.2, 2-7.

[29] Richardson, P. W. \& Watt, H. M. G. (2005). I've decided to become a teacher: Influences on career change, Teaching and Teacher Education 21, 475-489.

[30] Richardson, P.W. \& Watt, H. M. G. (2006). Who chooses teaching and why? Profiling characteristics and motivations across three Australian universities, Asia-Pacific Journal of Teacher Education 34.1, 27-56.

[31] Saban, A. (2003). A Turkish profile of prospective elementary school teachers and their views of teaching, Teaching and Teacher Education 19, 829-846.

[32] Scrivener, J. (1994). Learning to teach. Oxford: Oxford University Press.

[33] Sinclair, C. (2008). Initial and changing student teacher motivation and commitment to teaching, Asia-Pacific Journal of Teacher Education 36.2, 79-104.

[34] Stronge, J. H. (2007). Qualities of efffective teachers ( $2^{\text {nd }}$ edn). Alexandria, VA: Association for Supervision and Curriculum Development.

[35] Super, D. E. (1953). A theory of vocational development. American Psychologist 8, 185-190.

[36] Taylor, A. (2006). Perceptions of prospective entrants to teacher education, Teaching and Teacher Education 22, $451-464$.

[37] Watt, H. M. G. \& Richardson, P. W. (2007). Motivational factors influencing teaching as a career choice: development and validation of the FIT-choice scale, The Journal of Experimental Education 75.3, 167-202.

[38] Watt, H. M.G., Richardson, P.W., \& Tysvaer, N.M. (2007). Profiles of beginning teachers' professional engagement and career development aspirations (Ch 10, pp. 155-176). In A. Berry, A. Clemans, \& A. Kostogriz (eds.), Dimensions of professional learning: Professionalism, practice and identity. Rotterdam, The Netherlands: Sense Publishers.

[39] Wigfield, A., \& Eccles, J.S. (2000). Expectancy-value theory of achievement motivation, Contemporary Educational Psychology 25, 68-81.

[40] Yong, B.C.S. (1995). Teacher trainees' motives for entering into a teaching career in Brunei Darussalam, Teaching and Teacher Education 11.3, 215-280.

Ece Zehir Topkaya is a lecturer at Faculty of Education, ELT Department at Çanakkale Onsekiz Mart University. Her research interests include pre and in-service language teacher education and psychology of learning.

Mehmet Sercan Uztosun is a research assistant at Faculty of Education, ELT Department at Çanakkale Onsekiz Mart University and EdD Candidate at Graduate School of Education, University of Exeter, UK 